\title{
Tourism and degrowth: an emerging agenda for research and praxis
}

\author{
Robert Fletcher ${ }^{a}$, Ivan Murray Mas ${ }^{b}$, Asunción Blanco-Romero ${ }^{c}$ (D) and \\ Macià Blázquez-Salom ${ }^{\mathrm{d}}$

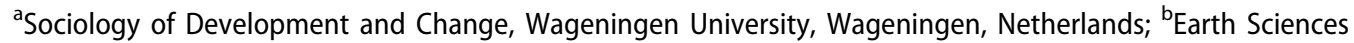 \\ Department, Universitat de les Illes Balears, Palma de Mallorca, Spain; 'Departament de Geografia, \\ Universitat Autònoma de Barcelona, Bellaterra, Spain; ${ }^{d}$ Earth Science Department, Universitat de Les Illes \\ Balears, Palma de Mallorca, Spain
}

\begin{abstract}
This article outlines a conceptual framework and research agenda for exploring the relationship between tourism and degrowth. Rapid and uneven expansion of tourism as a response to the 2008 economic crisis has proceeded in parallel with the rise of social discontent concerning so-called "overtourism." Despite decades of concerted global effort to achieve sustainable development, meanwhile, socioecological conflicts and inequality have rarely reversed, but in fact increased in many places. Degrowth, understood as both social theory and social movement, has emerged within the context of this global crisis. Yet thus far the vibrant degrowth discussion has yet to engage systematically with the tourism industry in particular, while by the same token tourism research has largely neglected explicit discussion of degrowth. We bring the two discussions together here to interrogate their complementarity. Identifying a growth imperative in the basic structure of the capitalist economy, we contend that mounting critique of overtourism can be understood as a structural response to the ravages of capitalist development more broadly. Debate concerning overtourism thus offers a valuable opportunity to re-politicize discussion of tourism development generally. We contribute to this discussion by exploring of the potential for degrowth to facilitate a truly sustainable tourism.
\end{abstract}

\section{ARTICLE HISTORY}

Received 19 September 2019

Accepted 20 September 2019

\section{KEYWORDS}

Degrowth; overtourism; political economy; political ecology; platform capitalism

\section{Introduction}

On 22 May 2019, Nirmal Purja, a mountaineer and former British soldier, published a photograph of his view from the rear of a long queue of climbers snaking towards the summit of Mt. Everest. This image quickly went viral (see Hill, 2019), prompting - combined with the fact that this congestion led to the death of at least five other climbers in the days surrounding the photo's publication - widespread complaints that the peak had become dangerously overcrowded (e.g., Beaumont, 2019). This event crystallized several years of increasingly vocal critique in popular destinations worldwide concerning a phenomenon now commonly labelled "overtourism", which the United Nations World Tourism Organization (UNWTO) defines as "the impact of tourism on a destination, or parts thereof, that excessively influences perceived quality of life of 
citizens and/or quality of visitors experiences in a negative way" (2018, p. 4). How had it reached the point, critics now complained, that such overcrowding had come to affect even the highest point on Earth?

At the heart of this discussion stands the sustained yearly increase in growth the global tourism industry has experienced since at least 1950, which the United Nations World Tourism Organization (UNWTO) (2019) claims averages 4\% per annum. Critique of overtourism thus calls into question this growth itself and the extent to which it can remain sustainable in the face of a mounting range of negative impacts. In this way, the critique touches the heart of discussion concerning the potential for sustainable tourism more generally. As we demonstrate further below, the bulk of this discussion takes as its starting point the necessity of sustaining tourism growth. Yet if this growth is itself an essential obstacle in the face of sustainability then this perspective may need to be questioned in its entirety.

In this way, the overtourism discussion dovetails with longstanding critique of a similar growth imperative at the heart of sustainable development policy more generally (e.g., Escobar, 1995; Wanner, 2015). An increasingly popular response to this imperative has been a call to move away from a growth-based economy altogether and instead pursue "degrowth." Emerging from a conjunction of activist social movements and critical scholarship, degrowth is a proposal for a radical socio-political transformation, for a "planned economic contraction" (Alexander, 2012) intended to shift the societal metabolic regime towards a decabornized one based on lower material throughput. In contrast to proposals for "decoupling," "dematerialization" or "green growth" (see e.g., Fletcher \& Rammelt, 2017; Parrique et al., 2019; Smil, 2013), degrowth advocates a re-politization of sustainability discourse and radical transformation of the political economy within which sustainability is pursued (Asara, Otero, Demaria, \& Corbera, 2015). It includes calls to (re)build societies and economies around principles of commons creation and governance, care and conviviality (see esp. D'Alisa, Demaria, \& Kallis, 2014).

Research and advocacy concerning degrowth has developed rapidly over the last decade in particular (see Kallis et al., 2018). Yet to date this discussion has, with few exceptions (outlined below), largely neglected sustained attention to tourism specifically. Tourism is, however, one of the world's largest industries and hence a main form of global economic expansion (Fletcher, 2011; United Nations World Tourism Organization (UNWTO), 2019). Moreover, the industry is forecasted to continue to grow dramatically into the foreseeable future as the basis of the development aspirations of many low- and high-income societies alike (United Nations World Tourism Organization (UNWTO), 2019). To seriously pursue degrowth at both global and most national levels would, therefore, likely require drastic transformation of the tourism industry and its metabolism.

By the same token, notwithstanding important initial explorations (also detailed below), widespread discussion of the potential for sustainable tourism has thus far neglected to seriously engage with the discourse of degrowth. This collection thus seeks to bring discussions of sustainable tourism and degrowth together as a foundation for future research and praxis. In this introduction to the collection, we describe the building blocks upon which this discussion is erected then explore how it is operationalized in the ten articles that follow. Our overarching aim is to contribute to exploration of the potential for degrowth to facilitate a truly sustainable tourism, promoting academic discussion particularly within the fields of political economy and political ecology of tourism.

We begin by outlining the mounting discussion of overtourism, explaining how it builds on yet also departs from a venerable tradition of critique concerning the myriad negative impacts of conventional tourism development. We then describe how "sustainable tourism" has been promoted as an antidote to these problems. Here we elaborate our previous assertion that this discussion has, like sustainable development writ large, generally taken sustained growth as its starting point ( as Michael Redclift pointed out already in the late 1980s; see Redclift, 1987, 2018). We identify this growth imperative in the basic structure of the capitalist economy, which demands continual growth in order to stave off internal contradictions that would otherwise 
threaten its survival. From this perspective, tourism growth can be seen to provide essential support to the global capitalist system as a whole (Fletcher, 2011). We show how this imperative has intensified since the 2008 economic crisis, after which stimulation of tourism growth has been increasingly relied upon as a mechanism for economic recovery more generally. This has been compounded by the rise of so-called platform capitalism in the same period, whereby "cyberspace" has been harnessed as a new arena for time-space displacement of excess accumulated capital (Harvey, 1982, 1989), in terms of which tourism development can be seen to function as an associated capitalist fix (Fletcher, 2011; Fletcher \& Neves, 2012). In our analysis, consequently, critique of overtourism can be understood as a structural response to the ravages of capitalist development more broadly - a far cry from its frequent dismissal as a form of "antitourism" or even "tourism-phobia" ( for discussion see esp. Milano, 2017a, 2017b). Overtourism, we contend, must therefore provoke reconsideration of the political economy of tourism as a whole and not merely debate concerning the appropriate number of tourists ("carrying capacity") within a given location. From this perspective, the question of overtourism and its proliferation offers a valuable opportunity to re-politicize tourism development within critical inquiry on the part of both academia and social movements.

From there we turn to degrowth, outlining a vibrant groundswell of research and practice concerning this theme that has proliferated over the past decade. Returning to discussion of capitalism's growth imperative, we build on Foster's (2011) early contention that degrowth within capitalism constitutes an "impossibility theorem" to argue that serious degrowth likely demands pursuit of post-capitalism. Moving back to tourism once more, we outline the small spate of previous research pointing to the potential for degrowth to facilitate a truly sustainable tourism. Here again we emphasize that this must go beyond capitalist development to pursue post-capitalist forms of production, consumption and exchange. We finish by outlining how other researchers can build on all of this to elaborate various aspects of the analysis further in the future and how the different articles in the special collection initiate this important project.

\section{(Over)tourism and its discontents}

Discussion of overtourism grew exponentially over the last decade to become one of "the buzzwords of 2017" (Milano, Cheer, \& Novelli, 2019, p. 354) and focus of a burgeoning literature in both popular and scholarly media (see esp. Koens, Postma, \& Papp, 2018; Milano, 2017a, 2017b; Milano, Cheer et al., 2019; Milano, Novelli, \& Cheer, 2019; United Nations World Tourism Organization (UNWTO), 2018). This literature has documented an increasingly critical response to tourism expansion in a wide range of the world's most popular destinations, including Amsterdam, Athens, Barcelona, Berlin, Dubrovnik, Lisbon, London, Malaga, Palma (Mallorca), Paris, Reykjavík, Venice and many more.

As most contributors to the overtourism discussion acknowledge, concern with the negative impacts of tourism development is anything but new. On the contrary, growing discontent with these impacts, on the part of both residents and visitors, has frequently accompanied such development in destinations throughout the world. Globally, discontent with the impacts of unfettered tourism development promoted scathing critique from the Ecumenical Coalition on Third World Tourism as early as 1992, which succinctly summarized many of the most common concerns in asserting:

[T]ourism, especially Third World Tourism, as it is practiced today, does not benefit the majority of people. Instead it exploits them, pollutes the environment, destroys the ecosystem, bastardizes the culture, robs people of their traditional values and ways of life and subjugates the women and children in the abject slavery of prostitution. In other words, tourism epitomises the present unjust world economic order where the few who control wealth and power dictate the terms. As such, tourism is little different from colonialism. (Srisang, 1992, p. 3, cited in Mowforth \& Munt, 2016, p. 58). 
Consequently, a substantial portion of tourism research has long been devoted to documenting and explaining discontent of this sort. In his controversial Tourism: Blessing or Blight?, Young (1973) had in the 1970s already raised many of the issues that are still at the forefront of critical tourism studies, including impacts related to tourism growth. Building on this, Butler's (1980) famous Tourism Area Life Cycle (TALC) model depicts a series of regular phases of destination development leading to stagnation and decline if not proactively addressed. Doxey (1975), meanwhile, offers an "Irritation Index" depicting am evolution towards increasing hostility in hosts' attitudes vis-à-vis visitors as tourism expands.

Despite this long pedigree of discontent concerning tourism development, however, there does seem to be something particular and unprecedented about the present moment, wherein a common set of complaints have been voiced by different sets of actors in so many disparate places simultaneously. This pattern suggests that we are dealing with something systemic and structural that has yet to be highlighted by the existing overtourism literature. In what follows, we offer an original structural analysis of the causes and consequences of the current wave of overtourism as a foundation for our subsequent discussion of the potential for degrowth to offer a constructive response to it. We begin by delving deeper into the nature of the "sustainable tourism" that is frequently advocated as a corrective to the negative impacts of conventional tourism development outlined above.

\section{A "sustainable" tourism development?}

The dominant response to adverse impacts of conventional tourism development has always been to call for transition to a "sustainable" form of tourism, as exemplified by this journal among many other media. Such calls have paralleled the rise of sustainable development policy more generally and have similarly defined sustainability in terms of the conventional three pillars highlighting interrelated environmental, social, and economic dimensions (Mowforth \& Munt, 2016). Like sustainable development (see Hopwood, Mellor, \& O'Brien, 2005), what precisely sustainable tourism means has always been understood differently by different people (Butler, 1999). Yet foundational to both discussions has long been a common concern to sustain economic growth as the basis for both projects (Naess \& Høyer, 2009). As the UN's foundational Bruntland Report famously asserted,

Far from requiring the cessation of economic growth, [sustainable development] recognizes that the problems of poverty and underdevelopment cannot be solved unless we have a new era of growth in which developing countries play a large role and reap large benefits (World Commission on Environment and Development (WCED), 1987, p. 40).

This perspective has been reiterated in the newly implemented Sustainable Development Goals (SDGs), which include tourism development as one explicit foci and readily admit their central concern to promote "sustained, inclusive and sustainable economic growth" (United Nations (UN), 2016). Nonetheless, and despite sustainable tourism's popularity as a widespread buzzword, business-as-usual scenarios forecast a dramatic expansion of tourism and its impacts in coming years (Gössling \& Peeters, 2015).

Yet it is this very growth that has prompted mounting concern within discussions of overtourism. Again, as with sustainable development broadly, such concern is commonly met with assertions that a shift to "green growth" based in "decoupling" can reconcile sustainability with continued economic expansion (see e.g., United Nations Environment Programme (UNEP), 2011a, 2011b). Yet abundant evidence questions whether such green growth is actually attainable (Fletcher \& Rammelt, 2017; Hickel \& Kallis, 2019; Parrique et al., 2019). And even if it were this would not address the social implications of tourism expansion at the heart of the overtourism discussion. 
Consequently, questioning growth itself as the basis of sustainable tourism has now become part of sustainable tourism discourse (Büscher \& Fletcher, 2017; Fletcher, 2019; Hall, 2009, 2010; Higgins-Desbiolles, 2010, 2018). Higgins-Desbiolles, for instance, asserts that the global tourism industry "is addicted to growth, which is incompatible with sustainability goals" (2018, p. 157). Consequently, she argues that achieving a truly "sustainable tourism necessitates a clear-eyed engagement with notions of limits that the current culture of consumerism and pro-growth ideology precludes" (Higgins-Desbiolles, 2010, p. 125). Fletcher, similarly, calls for a "new model [of] tourism management, as well as economic governance more generally, that does not depend on continual growth" (2019, p. 532). Yet achieving this entails addressing the nature of the politicaleconomic system within which most tourism is embedded. We turn to this in the next section.

\section{Tourism growth as capitalist "fix"}

Frequently underappreciated within tourism studies is the extent to which the industry can be understood not merely as an instrument of capitalist development (Britton, 1991; Bianchi, 2009; Mosedale, 2011, 2016) but as a primary means by which the capitalist system as a whole sustains itself in the face of fundamental contradictions that threaten its long-term survival (Fletcher, 2011). This analysis begins with understanding the ways that various spatial and/or temporal "fixes" help to resolve problems of capital overaccumulation more broadly via displacing excess capital through time and space and thereby helping to resolve crisis in the short term (Harvey, 1982, 1989; Smith, 1984). As a principle capitalist industry, tourism development can be seen to offer a whole series of such fixes for the capitalist system more generally (Fletcher, 2011; Fletcher \& Neves, 2012).

It should be little surprise, consequently, that one of the most common responses to the 2008 global economic crisis was to endeavor to re-stimulate tourism growth as a stimulus to economic recovery generally (Murray, 2015). This was, Harvey (2010) explains, a textbook overaccumulation crisis in which global production outstripped demand - even with the copious quantity of cheap credit available to many consumers - and hence precipitated a deep and persistent recession. As a sink for reinvestment of this accumulated capital, tourism development could thus help to resolve this recession. Hence the UNWTO, in a self-styled "Roadmap to Recovery" published shortly after the initial collapse (in March 2009), asserted the need to resume tourism growth, in the interest of which "it is now crucial to remove all obstacles to tourism, especially taxation and over regulation" (United Nations World Tourism Organization (UNWTO), 2009a, 2009b). For this to occur it was deemed imperative for "governments to remove unnecessary regulatory and bureaucratic restrictions on travel which hamper its flow and reduce its economic impacts" (ibid.). Specifically, the organization recommended state intervention to "boost trade, simplify regulation, build infrastructure and rationalize taxes" (ibid.).

Heeding such advice, nations around the world undertook an unprecedented push to attract increased tourism flows as a means not only to re-stimulate the industry but to promote economic recovery more broadly (Nicolae \& Sabina, 2013; Murray, 2015; Murray, Yrigoy, \& BlázquezSalom, 2017). In this spirit, then UNWTO Secretary-General Taleb Rifai asserted in 2013 that "international tourism continues to grow above expectations, supporting economic growth in both advanced and emerging economies and bringing much needed support to job creation, GDP and the balance of payments of many destinations" (United Nations World Tourism Organization (UNWTO), 2013). This was compounded by the rise of what has come to be called "platform capitalism" also in the wake of the 2008 crisis (see Langley \& Leyshon, 2017; Rushkoff, 2016; Slee, 2017; Srnicek, 2017). Platform capitalism comprises "digital infrastructures that enable two or more groups to interact" (Srnicek, 2017, p. 43). These platforms seek to centralize and capture activity within a particular domain and thereby appropriate the monopoly rents generated by this privileged market position. The most prominent platforms globally include Amazon, 
Google, and Facebook (in the realms of online commerce, web searching and social media, respectively). Srnicek (2017, p. 49-50) distinguishes five main types of platforms:

1. "advertising platforms (e.g. Google, Facebook), which extract information on users, undertake a labour of analysis, and then use the products of that process to sell ad space."

2. "cloud platforms (e.g. AWS, Salesforce), which own the hardware and software of digitaldependent businesses and are renting them out as needed."

3. "industrial platforms (e.g. GE, Siemens), which build the hardware and software necessary to transform traditional manufacturing into internet-connected processes that lower the costs of production and transform goods into services."

4. "product platforms (e.g. Rolls Royce, Spotify), which generate revenue by using other platforms to transform a traditional good into a service and by collecting rent or subscription fees on them."

5. "lean platforms (e.g. Uber, Airbnb), which attempt to reduce their ownership of assets to a minimum and to profit by reducing costs as much as possible."

The "lean" platform Airbnb is the main arena of contention within the tourism industry (BlancoRomero, Blázquez-Salom, \& Cànoves, 2018; Crommelin, Troy, Martin, \& Pettit, 2018; Roelofsen \& Minca, 2018). In providing the opportunity for ordinary residents (and increasingly, large firms as well) to offer their private spaces for rental to inbound tourists, Airbnb, along with a number of similar if smaller platforms, has enabled a dramatic expansion of tourism into areas previously outside of the major tourism circuits. Common consequences of this expansion include sharp increases in real estate and rental prices and subsequent displacement of residents in favor of transient visitors, thereby transforming the character of entire neighborhoods and cityscapes (see esp. Blanco-Romero, Blázquez-Salom, \& Cànoves, 2018; Cocola-Gant \& Gago, 2019).

Srnicek contends that the rise of platforms can be understood as a direct response to the 2008 crisis, in the aftermath of which "capitalism has turned to data as one way to maintain economic growth and vitality in the face of a sluggish production sector" (2017, p. 6). Digital platforms are a particularly seductive arena for pursuit of capital accumulation in an era of general stagnation, in that "the ability to rapidly scale many platform businesses by relying on preexisting infrastructure and cheap marginal costs means that there are few natural limits to growth" (Srnicek, 2017, p. 45). In this way, platforms offer an entirely new arena - cyberspace in which to pursue time-space fixes for the overaccumulation crisis.

From this political economic perspective, current discussion of overtourism must be understood as a product of structural dynamics within the global capitalist system as a whole. This provides a very different vantage point than the common focus on the ostensibly "anti-tourist" or even "tourism-phobic" attitudes commonly ascribed to disgruntled residents (see Milano, 2017a; Blanco-Romero, Blázquez-Salom, \& Morell, 2018; Blanco-Romero, Blázquez-Salom, Morrell, \& Fletcher, 2020). Rather, it places the focus squarely on a systemic push towards tourism growth more broadly pursued by powerful actors at local, national and global levels simultaneously. Widespread pushback against overtourism is thus a reflection of this campaign. This response may therefore be understood as something of a Polanyian double movement, in terms of which capitalist development commonly provokes popular resistance contesting the negative impacts of this development (Polanyi, 1944). More than this, it can be seen as what Nancy Fraser labels a "triple movement" that goes beyond the state-centered "social protection" central to Polanyi's analysis to advocate an autonomous, emancipatory politics pursued beyond state institutions (Fraser, 2013; Fraser \& Jaeggi, 2018). And if the problem to which these movements respond is promotion of tourism growth itself, then a potential resolution to this conflict would be to instead demand containment of such growth, either through social protection (a double movement) or, as we are increasingly witnessing, calls for tourism degrowth (a triple movement) altogether. 


\section{Enter degrowth}

The theoretical and political fundaments that nourish degrowth can be traced back at least to the 1960s and 1970s in the early voices in political and social ecology (e.g., André Gorz, Jacques Ellull, Ivan Illitch, Cornelius Castoriadis, Murray Bookchin, and Manuel Sacristán) as well as ecological economics (e.g., Nicolai Georgescu-Roegen, Joan Martínez-Alier, Herman Daly and José Manuel Naredo). Although many of those thinkers did not explicitly mentioned the term degrowth they are crucial for introducing some of the key ideas and questions that would subsequently be elaborated in the degrowth literature. Explicit discussion of degrowth has grown quickly since the turn of the twentyfirst century in particular to comprise a number of interconnected threads (for a useful recent overview see Kallis et al., 2018). However, it is important to acknowledge that other political and scholarly projects very similar to degrowth have developed in parallel utilizing different concepts, such as Sumak Kawsay or Buen Vivir (Kothari, Salleh, Escobar, Demaria, \& Acosta, 2019; see also below).

In an influential stream of initial discussion in the early 2000 s, Latouche (2003, p. 3-4) contributed to degrowth discourse by defining it as "a necessity, not a principle, an ideal, but the objective of a post-development society." His thesis was rooted in the idea of achieving social prosperity without the need for the infinite growth demanded by mainstream development pundits. Latouche $(2006,2007)$ claimed to unravel the contradictions entailed in pursuit of unlimited growth by defining this as precisely what degrowth is not. In this way, he responded to common criticisms in arguing that degrowth does not intend to condemn impoverished countries to poverty, nor does it mean zero growth, nor a return to the past, nor to a patriarchal or authoritarian social order incompatible with democracy.

Building on this foundational work by Latouche and others, the degrowth conversation has developed through social activism within the new century, been elaborated through a series of international conferences held yearly since 2008 (D'Alisa, Demaria, \& Cattaneo, 2013), and been propagated through a great profusion of recent academic writing (see inter alia Akbulut, Demaria, Gerber, \& Martinez-Alier, 2019; Cattaneo, D’Alisa, Kallis, \& Zografos, 2012; D'Alisa et al., 2014; Demaria, Kallis, \& Bakker, 2019; Kallis, Schneider, \& Martinez-Alier, 2010; Kallis, Kerschner, \& Martinez-Alier, 2012a; Kallis, Kerschner, \& Martinez-Alier, 2012b; Paulson, 2017; Saed, 2012; Sekulova, Kallis, Rodríguez-Labajos, \& Schneider, 2013). Links among such initiatives have facilitated their scaling up into national and transnational networks (D'Alisa et al., 2013).

Within this diverse discussion, degrowth is understood in different ways, from a narrow economic transformation to a far broader cultural paradigmatic shift. Central to most strands of degrowth discourse, however, is "to understand critically and undo the phenomenon of growth - a material, ecological, historical, discursive and institutional phenomenon that is at the heart of the Western imaginary and its colonial dominance - and to propose alternatives to it" (Kallis, 2018 , p. 9). This project comprises both macro- and micro-level initiatives. At the macroeconomic level, "degrowth refers to a trajectory where the 'throughput' (energy, materials and waste flows) of an economy decreases while welfare, or well-being, improves" (Kallis, 2018, p. 9). Specific proposals for implementing such a shift include:

\footnotetext{
resource and $\mathrm{CO} 2$ caps; extraction limits; new social security guarantees and work-sharing (reduced work hours); basic income and income caps; consumption and resource taxes with affordability safeguards; support of innovative models of "local living"; commercial and commerce free zones; new forms of money; high reserve requirements for banks; ethical banking; green investments; cooperative property and cooperative firms. (Kallis et al., 2012b, p. 175)
}

At the micro-level, meanwhile, degrowth proponents advocate activities such as "cycling, carsharing, reuse, vegetarianism or veganism, co-housing, agro-ecology, eco-villages, solidarity economy, consumer cooperatives, alternative (so-called ethical) banks or credit cooperatives as well as decentralized renewable energy cooperatives" (D'Alisa et al., 2013, p. 218).

As a discussion emerging primarily from the high-income Global North, degrowth's applicability to low income and Southern societies has been questioned (Escobar, 2015; Rodríguez-Labajos 
et al., 2019). Thus Escobar depicts a widespread perception "that degrowth is 'ok for the North' but that the South needs rapid growth, whether to catch up with rich countries, satisfy the needs of the poor, or reduce inequalities" (2015, p. 6). Yet degrowth advocates commonly call not merely for economic contraction but rather "contraction and convergence" - that is, economic degrowth in societies experiencing excessive resource use and (limited) growth in others. Yet growth alone cannot redress inequality within a capitalist system based on uneven geographical development (Smith, 1984). Hence, as Daly (2008, p. 12) reminds us, "Without aggregate growth poverty reduction requires redistribution." For degrowth to be "socially sustainable" (Martinez Alier, 2009) in any society therefore demands dramatic redistribution in control of existing land, wealth and resources.

A common misunderstanding equates degrowth with simple economic decline or recession. Yet as Kallis and colleagues explain, "involuntary declines are not degrowth in themselves, and countries in recession or depression are not degrowth experiments" (2018, p. 294). In this sense, moments and places of crisis, economic busts, burst financial bubbles, natural disasters, and similar events have nothing to do with degrowth. Rather, degrowth can be conceptualized as a "radical political and economic reorganization leading to drastically reduced resource and energy throughput" (Kallis et al., 2018, p. 291).

An important question concerns the extent to which degrowth is compatible with a capitalist economy and society (Foster, 2011; Liodakis, 2018). Raising this question some time ago, Foster indeed pronounced degrowth within capitalism an "impossibility theorem," arguing, "The ecological struggle... must aim not merely for degrowth in the abstract but more concretely for deaccumulation - a transition away from a system geared to the accumulation of capital without end" (2011, p. 33, emphasis in original). Responding to this challenge, Kallis and co-authors indeed acknowledge that "[c]apitalist economies can ... either grow or collapse: they can never degrow voluntarily" (2012b, p. 177), and hence that degrowth advocacy often "fails to explain how a capitalist economy would work without a positive profit rate, a positive interest rate or discounting." Summarizing this discussion more recently, Kallis concludes, "Growth is part and parcel of capitalism: abandoning the pursuit of growth requires a transition beyond capitalism" (2018, p. 163). Yet in contrast to some post-capitalist literature that envisions a future of abundance enabled by information technology (i.e., the internet of things, which will, ostensibly, lead to abolition of the law of value, echoing Rifkin's (2014) argument for a 'zero marginal cost' society) (e.g., Bastani, 2019; Mason, 2015; Srnicek \& Williams, 2015), degrowth advocates tend to eschew techno-promethean utopias and instead take seriously the need for a metabolic shift towards a future entailing living with less and with a lower footprint (Kerschner, Wächter, Nierling, \& Ehlers, 2018) - what Latouche (2009) calls "frugal abundance" and Salleh (2009) "ecofeminist sufficiency."

\section{Tourism and degrowth}

Potential for degrowth has been explored in relation to a variety of economic sectors and other social spaces. Yet application of the perspective to the realm of tourism has been relatively limited thus far. Bourdeau and Berthelot (2008) offer an initial exploration of this potential in a contribution to the first international degrowth conference in Paris in 2008. This was then elaborated by Hall, who asserted that "the contribution of tourism to sustainable development should be understood in the context of degrowth processes that offer an alternative discourse to the economism paradigm that reifies economic growth in terms of GDP" (2009, p. 46). To operationalize this alternative, Hall advocated a "steady-state tourism ... that encourages qualitative development but not aggregate quantitative growth to the detriment of natural capital (2010, p. 131). Building on all of this, Büscher and Fletcher subsequently assert, "Tourism, clearly, must not just come to terms with the fact that its exponential growth has to halt, but that it 
needs to radically 'degrow' in line with broader, more sustainable patterns of consumption and production" (2017, p. 664). In a rare empirical intervention in this discussion, meanwhile, PanzerKrause (2019) identifies a nascent degrowth-oriented faction within a network of ecotourism operators in rural Ireland.

The most sustained exploration of the potential for degrowth within tourism thus far is provided by Andriotis (2018). While he spends some time outlining core degrowth principles and their potential to facilitate sustainable tourism promotion more generally, his focus is primarily on the potential for individuals to travel in a manner that reduces resource use and other negative impacts - for instance, backpackers who move slowly between destinations and spend substantial time in one place trying to minimize consumption. In this way, Andriotis and others (e.g., Hall, 2009) point to the potential for tourism degrowth to converge with a variety of other campaigns seeking to reduce or reverse the negative impacts of tourism growth in various ways, including advocacy of "slow" (Fullagar, Markwell, \& Wilson, 2012), "responsible" (Spenceley, 2012), "pro-poor" (Scheyvens, 2009) and "justice" (Higgins-Desbiolles, 2008) tourism.

\section{Industry insiders defending growth}

Notwithstanding this small yet growing stream of commentary, a focus on tourism growth itself as a core obstacle to sustainable tourism remains far from popular within the overarching public sphere. On the contrary, it has been inspired heated reactions from industry insiders, who commonly portray tourism as a relatively "clean" sector whose growth is associated with increased economic welfare and job creation (Stroebel, 2015). From the consumer side, questioning tourism development implies questioning the very mechanisms that allow modern subjects to channel discontent produced by the increasing speed, competition and stress experienced in their work lives (Fletcher \& Neves, 2012). On the producer side, challenging mass tourism implies questioning hegemonic economic structures, provision of precarious/seasonal jobs, and increases in the prices of land/housing. In short, questioning tourism development is tantamount to challenging the current capitalist productive model and its growth imperative.

Consequently, the $11^{\text {th }}$ edition of the UNWTO/WTM Ministers' Summit (convened in November 2017 just as the overtourism discussion was peaking) carried the explicit title "Overtourism: growth is not the enemy; it is how we manage it" (World Trade Market (WTM) 2017). In announcing this meeting Rifai (2017) was quoted as asserting:

Growth is not the enemy. Growing numbers are not the enemy. Growth is the eternal story of mankind. Tourism growth can and should lead to economic prosperity, jobs and resources to fund environmental protection and cultural preservation, as well as community development and progress needs, which would otherwise not be available.

Following from this perspective, the dominant response to complaints of overtourism has thus far been to propose ways to better "manage" rather than question tourism growth. Hence, in its most elaborate contribution to the discussion, a report entitled 'Overtourism'? Understanding and Managing Urban Tourism Growth beyond Perceptions, the UNWTO asserts that "[t]ourism congestion is not only about the number of visitors but about the capacity to manage them" (United Nations World Tourism Organization (UNWTO), 2018, p. 5). At the same time, however, the report moves further towards actually addressing critics' concerns in also acknowledging, "Measures cannot focus only on altering tourist visitor numbers and tourist behaviour - they should also focus on local stakeholders. To ensure the positive aspects of tourism remain visible to and understood by residents, it is necessary to understand residents' concerns and grievances and include them in the tourism agenda" (United Nations World Tourism Organization (UNWTO), 2018, p. 7). Yet the laundry list of actions proposed to resolve the issue - from "Promot[ing] the dispersal of visitors within the city and beyond" to "Improv[ing] city infrastructure and facilities" 
- do little to tackle its root causes in the capitalist political economy and its imperative for continual growth to stave off overaccumulation crises.

At the municipal level, meanwhile, containment of tourism growth has in some places been partially assumed by public institutions seeking to regulate tourist accommodation capacity. (This can be understood as a double movement rather than the genuine degrowth envisioned as a civil society-based triple movement.) Measures introduced to operationalize this aim include: growth moratoria; management plans; eco-taxes and other special taxes on accommodation or traveling for tourism purposes; and limiting the capacity of transport infrastructure (airports, ports, highways, tunnels, bridges, etc.) or facilities (e.g., golf courses, ski slopes, marinas) (see Blázquez-Salom, 2006). Yet a common consequence of such measures is that their implementation generally causes a destination to become more expensive and elitist. In this way, regulations to merely contain tourism growth risk employing such measures in favour of the richest classes (Blázquez-Salom, 2016). The question of how to reconcile tourism degrowth with social equity thus remains fundamental.

\section{Towards a post-capitalist tourism?}

Initial exploration of the potential to pursue degrowth within tourism has largely neglected explicit discussion of the capitalist political economy underpinning most tourism development today. However, both social movements and critical scholarship contesting tourism commodification and promoting non-capitalist forms of tourism have highlighted issues and themes that could be embedded within a broad discussion of tourism degrowth (see e.g., Britton, 1978; Britton \& Clarke, 1989; Cañada \& Murray, 2019; Christine, 2014; Cordero, 2006; Gascón \& Cañada, 2005; Mowforth \& Munt, 2016; Wall, 1997). Building on this, Büscher and Fletcher (2017) explicitly link their advocacy of degrowth with critique of capitalist tourism and hence ask how "might tourism look if conceptualized from the point of view of a more general anti- or post-capitalist politics?" (2017, p. 664). They answer by asserting that "tourism should move radically from a private and privatizing activity to one founded in and contributing to the common" (2017, p. 664). Elsewhere, Fletcher expands on this to suggest that a properly post-capitalist tourism would pursue "(1) forms of production not based on private appropriation of surplus value; and (2) forms of exchange not aimed at capital accumulation; that (3) fully internalize the environmental and social costs of production in a manner that does not promote commodification and (4) are grounded in common property regimes" (2019, p. 532).

Advocacy of post-capitalism is certainly not to assume that merely moving away from capitalism is sufficient to reverse tourism growth. Actually existing socialist societies in the twentieth century, after all, were as deeply committed to pursuit of continual economic growth as the capitalist ones they contested. (Of course, it could also be argued with Wolff (2012) that such societies were not really socialist at all but rather forms of "state capitalism.") Consequently, "a transition beyond capitalism does not necessarily bring the abandonment of growth" (Kallis, 2018, p. 163). Rather, deliberate pursuit of degrowth, in tourism as elsewhere, "requires a systemic overhaul of established institutions, imaginaries and modes of living" (ibid.) with postcapitalism as its starting point. As with degrowth generally, it is important to distinguish between the type of simple decline in tourist numbers caused by such factors as economic crisis, loss of destination popularity or natural disaster, on the one hand, and on the other genuine tourism degrowth, which would require a concerted process of political-economic reorganization.

As with degrowth more generally, such a transition towards tourism degrowth could comprise both top-down and bottom-up elements, with pushes for systemic structural change at global and societal levels combined with more localized and individual practices contributing to downsizing on the ground. How the abstract principles of post-capitalist tourism outlined above might manifest within policy and practice at each of these scales remains largely unexplored thus far, 
however. Following Latouche, advocacy of touristic degrowth need not be viewed as wholesale denunciation of tourism per se - in other words, as an "anti-tourism" position, as popular media accounts often frame it. Rather, it is about searching for strategies for "de-touristification" in terms of which leisure activities are reconfigured, reorganized and practiced in different ways that aim to privilege local communities and ecosystems (Blanco-Romero, 2019).

\section{Outline of an agenda for research and praxis}

Building on the preceding discussion, we can begin to conceptualize a number of interrelated lines of inquiry for a future program of research and political engagement focused on the potential for tourism degrowth:

1. Tourism and sustainability as a political question (cf. Swyngedouw, 2010). This strand of analysis would use the banner of tourism degrowth as a strategy to re-politicize tourism development generally and sustainable tourism in particular.

2. Distribution of costs and benefits within tourism development and management. This line of research would undertake critical analysis of the political economy and political ecology of tourism's function as a form of capital accumulation, particularly in terms of who gains and who loses in the process of tourism development.

3. The biophysical limits to tourism growth. This research would investigate the social and biophysical costs of tourism development under capitalism, providing an assessment of the ecological costs and forms of metabolism entailed in this process.

4. Post-capitalist tourism in practice. This agenda would study practices of tourism degrowth (explicit or implicit) and their contradictions currently in operation or gestation throughout the world.

5. Commoning tourism and redistributing value. Following from the preceding, this line of investigation would explore the potential for tourism degrowth to transform the political and economic organization of the industry, particularly in pursuit of collectivization or redistribution of surplus value.

6. Tourism degrowth as de-touristification. This research would contribute to exploring the potential of tourism degrowth to function as de-touristification or "detourism" - that is, in reducing the intensity and impacts of tourism particularly in saturated destinations, and in this way facilitating a truly sustainable tourism.

7. The right to metabolism. This agenda would seek to more clearly define and conceptualize tourism degrowth as a reduction of the material and energy flows required by tourism capital, on the one hand, as well as a transformation of the political organization of material and energy flows within a triple movement scenario, on the other, in this way promoting the "right to metabolism" as a radical political project.

\section{Overview of the collection}

The articles that follow engage diverse aspects of the degrowth discussion via concrete case studies as well as more abstract theoretical exploration. While they do not all take post-capitalism as either their starting or ending point, they offer a productive basis for beginning to explore this potential. They also illustrate several of the lines of inquiry outlined above, providing a fertile foundation for further exploration of these themes.

Concerning the function of degrowth to serve as a provocation to re-politicize the question of sustainability within tourism development, Gascón (2019) leads off the collection by taking issue with growing assertions that travel should constitute a human right, advanced by the UNWTO and other industry insiders. He views this as preemptive attempt to squelch critique of 
the tourism growth imperative that degrowth among other perspectives mobilizes. Following Alston (1984), Gascón contends that such advocacy constitutes a "frivolous claim" that threatens both to distract from the need to consider touristic degrowth seriously and to trivialize the human rights discourse that it seeks to piggyback.

Turning to the theme of the political economy of tourism and its consequences, NavarroJurado et al. (2019) argue that tourism development in Malaga - the principle destination on Spain's fabled Costa del Sol - should be understood as a component of an "urban growth machine" (Logan \& Molotch, 1987) more generally that seeks to harness grand infrastructural projects as the engine of capital accumulation and expansion. They document a growing pushback against this development model by local social movements that have banded together to advance an alternative economic model emphasizing smaller-scale, bottom-up initiatives aimed to minimize environmental impact. The authors view this resistance as a symptom of a need to develop a more systematic planning process integrating tourism with other forms of development grounded explicitly in degrowth principles.

The next three contributions continue the focus on Spain's Mediterranean coast, where the promotion of tourism growth as an outlet for persistent economic crisis has been particularly intense, as has the social fallout from this promotion. The epicentre of this conflict is likely Barcelona, the focus of the intervention by Milano, Novelli, et al. (2019). They chart the rise of social movements critical of the impacts of ever-increasing tourist numbers that organized themselves under the label ABTS (Assemblea de Barris per un Turisme Sostenible [Assembly of Neighbourhoods for Sustainable Tourism]) and called explicitly for touristic degrowth ("decreixement turístic"). This movement then expanded outward to network with similar movements in other cities to constitute the Red de Ciudades del Sur de Europa ante la Turistización (Network of Southern European Cities against Touristification), or SET. The authors document how, despite initial resistance, the Barcelona government increasingly responded to these movements' demands by instituting a variety of measures aimed to mitigate tourism development and, in some spaces, actually degrow tourism facilities. They end on an ambivalent note by observing, on the one hand, that despite initial optimism some of these measures remain more in the realm of rhetoric than realization while, on the other hand, whatever its practical impact in situ the Barcelona discussion has nonetheless helped to stimulate a global debate concern the implications and future of tourism development generally.

Next, Valdivielso and Moranta (2019) take us off the coast to another popular destination the Balearic Islands - to explore mounting discussion of degrowth as a response to the dramatic recent surge in tourism arrivals to the islands. Through the lens of critical discourse analysis (CDA), they frame degrowth as a contested signifier that is adopted both to advocate for radical transformation of the tourism industry and to greenwash more reformist policy measures aimed merely to manage the industry's development. Based on this analysis, the authors conclude that the Balearic debate is not merely about different ways to address and manage tourism development but is in fact a "social struggle" that has stimulated the formation of "new democratic political subjects" and their organization within a revitalized civil society.

Building on the preceding contributions, Blázquez-Salom, Blanco-Romero, Vera-Rebollo, \& Ivars-Baidal (2019) offer a more synthetic overview of tourism development within the region. Comparing Barcelona, the Balearics and Valencia, they identify a growing prevalence of territorial planning measures intended to reduce or at least contain tourism expansion. Yet the authors assert that these ostensibly progressive processes suffer from crippling contradictions due to their inability to directly confront the capitalist accumulation model underlying the tourism growth they address. Consequently, they call for much stronger measures capable of transcending this accumulation model in pursuit of "genuine and fair degrowth."

Subsequently, Adityanandana and Gerber (2019) turn our focus to an entirely different region - Southeast Asia - to explore a potential example of tourism degrowth in practice. Their focus is a tourism megaproject in the Benoa Bay of Bali, Indonesia, whose development has been subject 
to fierce contestation by local interest groups that alternately support and denounce the project. Despite these differences, the authors find that local actors on different sides of the debate all espouse a similar philosophy of Tri Hita Karana (THK), translated as the "three causes of wellbeing." This perspective, however, is understood quite differently by different disputants within the debate. One prominent position the authors describe as a "radical-integral" perspective bearing "similarities with post-growth views" that, they contend, might be drawn upon to promote a degrowth-oriented approach to tourism development more broadly.

The next two articles continue this exploration of potential degrowth in practice by examining two similar cases of community-based ecotourism in the same country in South America: Ecuador. First, Renkert (2019) draws on Gibson-Graham's (2006) diverse economies framework to describe how involvement in a Kichwa-owned ecolodge "is locally embraced as a vehicle for livelihood wellbeing, cultural reclamation and environmental stewardship" grounded in a philosophy of Sumak Kawsay (commonly translated as Buen Vivir or the "good life"). While fully cognisant that small-scale projects of this sort cannot redress all of the ills associated with tourism overdevelopment, Renkert asserts that it still offers valuable lessons for how tourism can potentially be harnessed to cultivate a "localized degrowth society."

Taking the growing prominence of a Buen Vivir (BV) perspective generally with the country and region as their starting point, Chassagne and Everingham (2019) then examine how this philosophy is embodied within another community-based project in Ecuador's Cotacachi County. They explore how the BV principles embodied in this initiative resonate with the pillars of degrowth as conceptualized by Latouche (see above). Based upon this resonance, the authors assert that BV can provide the impetus for degrowing damaging extractive industries while simultaneously growing community-based tourism as a more socially and environmentally sustainable alternative. Importantly, however, they explain that within this process degrowth is a "consequence of BV, rather than the objective."

Taking us back to Europe once more, Oklevik et al. (2019) turn the focus from communitybased initiatives to how Destination Marketing Organisations (DMOs) such as government tourism bureaus might encourage tourism "optimization" as opposed to the dominant emphasis on "maximizing" visitor numbers. Based on a survey of international tourists in southwestern Norway, they ask whether an emphasis on promotion of varied "'activities', i.e., the development of local, small-scale and ideally more sustainable experiences, can contribute to economic growth without necessarily increasing numbers of arrivals". To facilitate further exploration for this potential they propose an innovative methodology that might be applied in other contexts as well.

Finally, Higgins-Desbiolles, Carnicelli, Krolikowski, Wijesinghe, and Boluk (2019) round out the collection by offering a provocative conceptual reflection on the rocky road that has led us to this moment of unprecedented public discussion concerning the potential for degrowth in tourism planning. Drawing on diverse examples from around the world, they demonstrate how continual expansion of the global tourism industry has increasingly been confronted by the spectre of "limits to growth" first conjured by the famous Club of Rome report in the early 1970s (Meadows, Meadows, Randers, \& Behrens, 1972). At the present juncture, the authors assert, the only way for the industry to truly achieve the sustainability it purportedly pursues is to rethink its aims fundamentally in order to refocus on degrowth. Central to this effort, they argue, must be an emphasis on supporting the rights of local community members over those of inbound tourists or firms comprising the tourism industry.

\section{Conclusion: another tourism is possible}

Tourism development, as we have shown, has become a principle fix for the 2008 financial crisis. The rapid and uneven expansion of tourism has proceeded in parallel with the rise of social 
discontent concerning so-called overtourism, which has affected particularly cities in the Global North. After decades of concerted global effort to achieve sustainable development, socioecological conflicts and inequality have rarely reversed, but in fact increased in many places. Degrowth, understood as both social theory and social movement, has emerged within the context of this global crisis. Since many authors and institutions have acknowledged that we have entered an age of economic stagnation combined with high levels of social inequality and expanding ecological degradation, the search for post-growth, post-capitalist, post-development and/or degrowth alternatives has become a social and intellectual imperative. In this regard, the agenda of tourism degrowth research that we have outlined herein aims to re-politicize the debate on sustainable tourism, where the point of this research should be not only to document and understand tourism development, but to contribute to its transformation (Castree, 2010).

In order to do so, we must first acknowledge the previous work by radical scholars who have long critically analyzed the socio-ecological costs of tourism - work that provides the foundation upon which a conceptual framework for analyzing tourism degrowth is erected. But most importantly, we must recognize the essential inspiration for this analysis in the organization of grassroots movements and their struggles against tourism dispossession, as well as the alternative and post-capitalist tourism projects such movements have nurtured. While many projects of this sort have not self-identified as degrowth initiatives per se, their vision and goals often match closely with principles of tourism degrowth. Since tourism degrowth is a proposal that aims to bring social movements and research/praxis together, scholars will have to pay particular attention to and cooperate with social movements to make another tourism possible within planetary boundaries.

\section{Disclosure statement}

No potential conflict of interest was reported by the authors.

\section{Funding}

This article was supported by the research project "Overtourism in Spanish coastal destinations: Tourism degrowth strategies" (RTI2018-094844-B-C31) funded by the Spanish Ministry of Science, Innovation and Universities.

\section{Notes on contributors}

Robert Fletcher is Associate Professor in the Sociology of Development and Change group at Wageningen University in the Netherlands. His research interests include tourism, development, conservation, globalization, climate change and social movements. He is the author of Romancing the Wild: Cultural Dimensions of Ecotourism (Duke University, 2014) and co-editor of NatureTM Inc.: Environmental Conservation in the Neoliberal Age (University of Arizona, 2014).

Ivan Murray holds PhD in Geography from the University of the Balearic Islands and a MsC in Environmental Sustainability from teh University of Edinburgh. He is Associate Professor of geography at the University of the Balearic Islands. He is member of the Research Group on Sustainability and Space. His research merges political ecology, political economy and ecological economics of tourism. He has recently co-edited with Ernest Cañada Turistificación global. Perspectivias críticas en turismo. He is also involved in social movements.

Asunción Blanco-Romero is Associate Professor of Geography at the Universitat Autònoma de Barcelona (Spain), and also participates with UNED (National University of Distance Education), UOC (Universitat Oberta de Catalunya) and OSTELEA School of Tourism and Hospitality. She is member of TUDISTAR research group (Tourism and new social and territorial dynamics), with which she has participated in several research projects. Her research focuses on cultural and heritage tourism, new tourisms and local development, tourism and degrowth, and geography and gender issues in regional development.

Macià Blázquez-Salom is Associate Professor in the Department of Geography at the University of the Balearic Islands. His research interests include tourism territorial planning and nature conservation from a sustainability 
perspective. He has been visiting scholar in several European and Central American universities. His most recent publications deal with urban and regional planning regulation and the expansion of the Balearic Islands' hotel chains in Central America and the Caribbean.

\section{ORCID}

Asunción Blanco-Romero (iD) http://orcid.org/0000-0002-5869-8603

\section{References}

Adityanandana, M., \& Gerber, J.-F. (2019). Post-growth in the tropics? Contestations over Tri Hita Karana and a tourism megaproject in Bali. Journal of Sustainable Tourism, 27(12), 1-18. doi:10.1080/09669582.2019.1666857

Akbulut, B., Demaria, F., Gerber, J.-F., \& Martinez-Alier, J. (2019). Ecological Economics 157, special issue on "Theoretical and political journeys between environmental justice and degrowth." doi:10.1016/j.ecolecon.2019. 106418

Alston, P. (1984). Conjuring up new human rights: A proposal for quality control. The American Journal of International Law, 78(3), 607-621. doi:10.2307/2202599

Alexander, S. (2012). Planned economic contraction: The emerging case for degrowth. Environmental Politics, 21(3), 349-368. doi:10.1080/09644016.2012.671569

Andriotis, K. (2018). Degrowth in tourism: Conceptual, theoretical and philosophical issues. New York, NY: CABI.

Asara, V., Otero, I., Demaria, F., \& Corbera, E. (2015). Socially sustainable degrowth as a social-ecological transformation: Repoliticizing sustainability. Sustainability Science, 10(3), 375-384. doi:10.1007/s11625-015-0321-9

Bastani, A. (2019). Fully automated luxury communism: A manifesto. London: Verso.

Beaumont, P. (2019, May 25). British climber latest to die on Everest amid overcrowding. Guardian. Retrieved from https://www.theguardian.com/world/2019/may/25/british-climber-latest-to-die-on-everest-amid-overcrowdingrobin-fisher

Bianchi, R. (2009). The 'critical turn' in tourism studies: A radical critique. Tourism Geographies, 11(4), 484-504. doi: $10.1080 / 14616680903262653$

Blanco-Romero, A. (2019). Decrecimiento turístico. In E. Cañada (Ed.). El turismo en la geopolítica del Mediterráneo (pp. 66-71). Barcelona: Alba Sud Editorial.

Blanco-Romero, A., Blázquez-Salom, M., \& Cànoves, G. (2018). Barcelona, housing rent bubble in a tourist city: Social responses and local policies. Sustainability, 10(6), 2043. doi:10.3390/su10062043

Blanco-Romero, A., Blázquez-Salom, M., \& Morell, M. (2018). La turismofobia como arma arrojadiza. Abaco: Revista de Cultura y Ciencias Sociales, 98, 55-64.

Blanco-Romero, A., Blázquez-Salom, M., Morrell, M., \& Fletcher, R. (2019). Understanding stakeholders' perceptions of urban touristification. BAGE. Forthcoming. doi:0.21138/bage.2834

Blázquez-Salom, M. (2006). Calmar, contenir ì decréixer: Polítiques provades (1983-2003) i possibles de planificació urbanística. Territoris, 6, 159-172.

Blázquez-Salom, M. (2016, May 26). Per on decréixer turísticament? Una alternativa ecosocialista. Alba Sud. Retrieved from http://www.albasud.org/blog/ca/883/c-mo-decrecer-tur-sticamente-una-alternativa-ecosocialista

Blázquez-Salom, M., Blanco-Romero, A., Vera-Rebollo, J. F., \& Ivars-Baidal, J. (2019). Territorial tourism planning in Spain: From boosterism to tourism degrowth? Journal of Sustainable Tourism. 27(12).

Bourdeau, P., \& Berthelot, L. (2008). Tourisme et decroissance: De la critique it l'utopie? In F. Flipo \& F. Schneider (Eds.), Proceedings of the First International Conference on Economic De-Growth for Ecological Sustainability and Social Equity, Paris, 18-19 April, pp. 78-85. Paris: Research \& Degrowth.

Britton, R. A. (1978). International tourism and indigenous development objectives. A study with special reference to the West Indies (PhD thesis). University of Minnesota, Minneapolis, MN.

Britton, S. (1991). Tourism, capital, and place: Towards a critical geography of tourism. Environment and Planning D: Society and Space, 9(4), 451-478. doi:10.1068/d090451

Britton, S., \& Clarke, W. C. (Eds.) (1989). Ambiguous alternative: Tourism in small developing countries. Suva: University of the South Pacific Press.

Butler, R. W. (1980). The concept of a tourist area cycle of evolution: Implications for management of resources. The Canadian Geographer/Le Géographe Canadien, 24(1), 5-12. doi:10.1111/j.1541-0064.1980.tb00970.x

Butler, R. W. (1999). Sustainable tourism: A state-of-the-art review. Tourism Geographies, 1(1), 7-25. doi:10.1080/ 14616689908721291

Büscher, B., \& Fletcher, R. (2017). Destructive creation: Capital accumulation and the structural violence of tourism. Journal of Sustainable Tourism, 25(5), 651-667. doi:10.1080/09669582.2016.1159214

Cañada, E., \& Murray, I. (Eds.) (2019). Turistificación global: Perspectivas críticas en turismo. Barcelona: Icaria. 
Castree, N. (Ed.) (2010). The point is to change it: Geographies of hope and survival in an age of crisis. New York, NY: John Wiley \& Sons.

Cattaneo, C., D'Alisa, G., Kallis, G., \& Zografos, C. (2012). Futures, 44(6), special issue on "Degrowth futures and democracy." doi:10.1016/j.futures.2012.03.012

Chassagne, N., \& Everingham, P. (2019). Buen Vivir: Degrowing extractivism and growing wellbeing through tourism. Journal of Sustainable Tourism, 27(12), 1-17. doi:10.1080/09669582.2019.1660668

Christine, R. (2014). L'Usure du monde: Critique de la déraison touristique. Paris: L'échappée.

Cocola-Gant, A., \& Gago, A. (2019). Airbnb, buy-to-let investment and tourism-driven displacement. A case study in Lisbon. Environment and Planning A. Forthcoming.

Cordero, A. (2006). Nuevos ejes de acumulación y naturalez: El caso del turismo. Buenos Aires: CLACSO.

Crommelin, K., Troy, L., Martin, C., \& Pettit, C. (2018). Is Airbnb a sharing economy superstar? Evidence from five global cities. Urban Policy and Research, 36(4), 429-444. doi:10.1080/08111146.2018.1460722

D'Alisa, G., Demaria, F., \& Cattaneo, C. (2013). Civil and uncivil actors for a degrowth society. Journal of Civil Society, 9(2), 212-224. doi:10.1080/17448689.2013.788935

D'Alisa, G., Demaria, F., \& Kallis, G. (Eds.). (2014). Degrowth: A vocabulary for a new era. London: Routledge.

Daly, H. (2008). A steady-state economy. Presentation for the UK Sustainable Development Commission, London, UK.

Demaria, F., Kallis, G., \& Bakker, K. (2019). Environment and Planning E, 2(3). special section on "Geographies of degrowth."

Doxey, G. V. (1975). A causation theory of visitor-resident irritants, methodology and research inferences. Conference Proceedings: Sixth Annual Conference of Travel Research Association, pp. 195-198. CTRA, San Diego, CA.

Escobar, A. (1995). Encountering development: The making and unmaking of the Third World. Princeton: Princeton University Press. doi:10.1086/ahr/101.5.1523

Escobar, A. (2015). Degrowth, postdevelopment, and transitions: A preliminary conversation. Sustainability Science, 10(3), 451-462. doi:10.1007/s11625-015-0297-5

Fletcher, R. (2011). Sustaining tourism, sustaining capitalism? The tourism industry's role in global capitalist expansion. Tourism Geographies, 13(3), 443-461. doi:10.1080/14616688.2011.570372

Fletcher, R. (2019). Ecotourism after nature: Anthropocene tourism as a new capitalist 'fix'. Journal of Sustainable Tourism, 27(4), 522-535. doi:10.1080/09669582.2018.1471084

Fletcher, R., \& Neves, K. (2012). Contradictions in tourism: The promise and pitfalls of ecotourism as a manifold capitalist fix. Environment and Society, 3(1), 60-77. doi:10.3167/ares.2012.030105

Fletcher, R., \& Rammelt, C. (2017). Decoupling: A key fantasy of the post-2015 sustainable development agenda. Globalizations, 14(3), 450-467. doi:10.1080/14747731.2016.1263077

Foster, J. B. (2011). Capitalism and degrowth: An impossibility theorem. Monthly Review, 62(8), 26-33. doi:10.14452/ MR-062-08-2011-01_2

Fraser, N. (2013). A triple movement? Parsing the politics of crisis after Polanyi. New Left Review, 81, 119-132.

Fraser, N., \& Jaeggi, R. (2018). Capitalism. A conversation in critical theory. Cambridge: Polity.

Fullagar, S., Markwell, K., \& Wilson, E. (Eds.). (2012). Slow tourism: Experiences and mobilities (Vol. 54). New York, NY: Channel View Publications.

Gascón, J. (2019). Tourism as a right: A "frivolous claim" against degrowth? Journal of Sustainable Tourism, 27(12), 1-14. doi:10.1080/09669582.2019.1666858

Gascón, J., \& Cañada, E. (2005). Viajar a todo tren: Turismo, desarrollo y sostenibilidad. Barcelona: Icaria.

Gibson-Graham, J. K. (2006). A postcapitalist politics. Minneapolis, MN: University of Minnesota Press.

Gössling, S., \& Peeters, P. (2015). Assessing tourism's global environmental impact 1900-2050. Journal of Sustainable Tourism, 23(5), 639-659. doi:10.1080/09669582.2015.1008500

Hall, C. M. (2009). Degrowing tourism: Décroissance, sustainable consumption and steady-state tourism. Anatolia, 20(1), 46-61. doi:10.1080/13032917.2009.10518894

Hall, C. M. (2010). Changing paradigms and global change: From sustainable to steady-state tourism. Tourism Recreation Research, 35(2), 131-143. doi:10.1080/02508281.2010.11081629

Harvey, D. (1982). The limits to capital. Chicago, IL: University of Chicago Press. doi:10.1086/ahr/88.5.1243

Harvey, D. (1989). The condition of postmodernity: An inquiry into the origins of cultural change. Oxford: Basil Blackwell.

Harvey, D. (2010). The Enigma of Capital: And the crises of capitalism. London: Profile Books.

Hickel, J., \& Kallis, G. (2019). Is green growth possible? New Political Economy, 1-18. doi:10.1080/13563467.2019. 1598964

Higgins-Desbiolles, F. (2008). Justice tourism and alternative globalization. Journal of Sustainable Tourism, 16(3), 345-364. doi:10.1080/09669580802154132

Higgins-Desbiolles, F. (2010). The elusiveness of sustainability in tourism: The culture ideology of consumerism and its implications. Tourism and Hospitality Research, 10(2), 116-129. doi:10.1057/thr.2009.31

Higgins-Desbiolles, F. (2018). Sustainable tourism: Sustaining tourism or something more? Tourism Management Perspectives, 25, 157-160. doi:10.1016/j.tmp.2017.11.017 
Higgins-Desbiolles, F., Carnicelli, S., Krolikowski, C., Wijesinghe, G., \& Boluk, K. (2019). Degrowing tourism: Rethinking tourism. Journal of Sustainable Tourism, 27(12), 1-19. doi:10.1080/09669582.2019.1601732

Hill, K. (2019, May 26). 'I became a traffic controller': Viral Everest photo's weird back story. Daily News. Retrieved from https://10daily.com.au/news/a190527cgbsr/i-became-a-traffic-controller-viral-everest-photos-weird-backstory-20190528

Hopwood, B., Mellor, M., \& O’Brien, G. (2005). Sustainable development: Mapping different approaches. Sustainable Development, 13(1), 38-52. doi:10.1002/sd.244

Kallis, G. (2018). Degrowth (The economy: Key ideas). New York, NY: Agenda Publishing.

Kallis, G., Kerschner, C., \& Martinez-Alier, J. (2012a). The economics of degrowth. Ecological Economics, 84, $172-180$. doi:10.1016/j.ecolecon.2012.08.017

Kallis, G., Kerschner, C., \& Martinez-Alier, J. (2012b). Ecological Economics, 84, special section on "The economics of degrowth." doi:10.1016/j.ecolecon.2012.08.017

Kallis, G., Kostakis, V., Lange, S., Muraca, S., Paulson, S., \& Schmelzer, M. (2018). Research on degrowth. Annual Review of Environment and Resources, 43(1), 291-316. doi:10.1146/annurev-environ-102017-025941

Kallis, G., Schneider, F., \& Martinez-Alier, J. (2010). Journal of Cleaner Production, 18(6), special issue on "Growth, recession or degrowth for social equity and sustainability.

Kerschner, C., Wächter, P., Nierling, L., \& Ehlers, M. H. (2018). Degrowth and technology: Towards feasible, viable, appropriate and convivial imaginaries. Journal of Cleaner Production, 197(2), 1619-1636. doi:10.1016/j.jclepro. 2018.07.147

Koens, K., Postma, A., \& Papp, B. (2018). Is overtourism overused? Understanding the impact of tourism in a city context. Sustainability, 10(12), 4384. doi:10.3390/su10124384

Kothari, A., Salleh, A., Escobar, A., Demaria, F., \& Acosta, A. (Eds.) (2019). Pluriverse: A post-development dictionary. New Delhi: Tulika Books.

Langley, P., \& Leyshon, A. (2017). Platform capitalism: The intermediation and capitalisation of digital economic circulation. Finance and Society, 3(1), 11-31. doi:10.2218/finsoc.v3i1.1936

Latouche, S. (2003). Por una sociedad del decrecimiento. Le Monde Diplomatique, 97. Edición Española.

Latouche, S. (2006). Le Pari de la décroissance. Paris: Fayard.

Latouche, S. (2007). Petit traité de la décroissance sereine. Paris: Mille et Une Nuits.

Latouche, S. (2009). Farewell to growth. Cambridge: Polity.

Liodakis, G. (2018). Capital, economic growth, and socio-ecological crisis: A critique of de-Growth. International Critical Thought, 8(1), 46-65. doi:10.1080/21598282.2017.1357487

Logan, J., \& Molotch, H. (1987). Urban fortunes: The political economy of place. Berkeley, CA: University of California Press.

Martinez Alier, J. (2009). Socially sustainable economic de-growth. Development and Change, 40(6), 1099-1119. doi: 10.1111/j.1467-7660.2009.01618.x

Mason, P. (2015). Postcapitalism: A guide to our future. London: Penguin.

Meadows, D. H., Meadows, D. L., Randers, J., \& Behrens, W. W. III. (1972). The limits to growth: A report for the Club of Rome's project on the predicament of mankind. New York, NY: Universe Books.

Milano, C. (2017a). Turismofobia: Cuando el turismo entra en la agenda de los movimientos sociales. Marea Urbana, 1. Retrieved from https://mareaurbanabcn.wordpress.com/2017/04/25/turismofobia-cuando-el-turismo-entra-enla-agenda-de-los-movimientos-sociales/

Milano, C. (2017b). Overtourism y turismofobia: Tendencias globales y contextos locales. Barcelona: Ostelea School of Tourism \& Hospitality. Retrieved from https://www.researchgate.net/publication/323174699_Overtourism_y_ Turismofobia_Tendencias_Globales_y_Contextos_Locales

Milano, C., Cheer, J. M., \& Novelli, M. (Eds.) (2019). Overtourism: Excesses, discontents and measures in travel and tourism. New York, NY: CABI.

Milano, C., Novelli, M., \& Cheer, J. M. (2019). Overtourism and tourismphobia: A journey through four decades of tourism development, planning and local concerns. Tourism Planning and Development, 16(4), 353-357.

Mosedale, J. (Ed.). (2011). Political economy of tourism: A critical perspective. London: Routledge.

Mosedale, J. (Ed.). (2016). Neoliberalism and the political economy of tourism. London: Routledge.

Mowforth, M., \& Munt, I. (2016). Tourism and sustainability: Development, globalisation and new tourism in the Third World (4th ed.). London: Routledge.

Murray, I. (2015). Capitalismo y turismo en España: Del "milagro económico" a la "gran crisis". Barcelona: Alba Sud Editorial.

Murray, I., Yrigoy, I., \& Blázquez-Salom, M. (2017). The role of crises in the production, destruction and restructuring of tourist spaces: The case of the Balearic Islands. Investigaciones Turísticas, 13, 1-29.

Naess, P., \& Høyer, K. G. (2009). The emperor's green clothes: Growth, decoupling, and capitalism. Capitalism Nature Socialism, 20(3), 74-95. doi:10.1080/10455750903215753

Navarro-Jurado, E., Romero-Padilla, Y., Romero-Martínez, J. M., Serrano-Muños, E., Habegger, S., \& Mora-Esteban, R. (2019). Growth machines and social movements in mature tourist destinations: Costa del Sol—Malaga. Journal of Sustainable Tourism. 27(12). 
Nicolae, C., \& Sabina, M. (2013). Travel and tourism as a driver of economic recovery. Procedia Economics and Finance, 6, 81-88.

Oklevik, O., Gössling, S., Hall, C. M., Steen Jacobsen, J. K., Grøtte, I. P., \& McCabe, S. (2019). Overtourism, optimisation, and destination performance indicators: A case study of activities in Fjord Norway. Journal of Sustainable Tourism, 27(12), 1-19. doi:10.1080/09669582.2018.1533020

Panzer-Krause, S. (2019). Networking towards sustainable tourism: Innovations between green growth and degrowth strategies. Regional Studies, 53(7), 927-938. doi:10.1080/00343404.2018.1508873

Parrique, T., Barth, J., Briens, F., Kerschner, C., Kraus-Polk, A., Kuokkanen, A., \& Spangenberg, J. H. (2019). Decoupling debunked: Evidence and arguments against green growth as a sole strategy for sustainability. Bruxelles: European Environmental Bureau.

Paulson, S. (2017). Journal of Political Ecology, 24(1), special section on "Degrowth: Culture, power, and change." doi:10.2458/v24i1.20882

Polanyi, K. (1944). The great transformation: The political and economic origins of our time. Boston, MA: Beacon.

Redclift, M. C. (1987). Sustainable development: Exploring the contradictions. London: Methuen.

Redclift, M. C. (2018). Sustainable development in the age of contradictions. Development and Change, 49(3), 695-707. doi:10.1111/dech.12394

Renkert, S. R. (2019). Community-owned tourism and degrowth: A case study in the Kichwa Añangu community. Journal of Sustainable Tourism, 27(12), 1-16. doi:10.1080/09669582.2019.1660669

Rifai, T. (2017). Tourism: Growth is not the enemy; it's how we manage it that counts. Retrieved from http://media. unwto.org/press-release/2017-08-15/tourism-growth-not-enemy-it-s-how-we-manage-it-counts

Rifkin, J. (2014). The zero marginal cost society: The internet of things, the collaborative commons, and the eclipse of capitalism. New York, NY: Palgrave Macmillan.

Rodríguez-Labajos, B., Yánez, I., Bond, P., Greyl, L., Munguti, S., Ojo, G. U., \& Overbeek, W. (2019). Not so natural an alliance? Degrowth and environmental justice movements in the Global South. Ecological Economics, 157, 175-184. doi:10.1016/j.ecolecon.2018.11.007

Roelofsen, M., \& Minca, C. (2018). The Superhost: Biopolitics, home and community in the Airbnb dream-world of global hospitality. Geoforum, 91, 170-181. doi:10.1016/j.geoforum.2018.02.021

Rushkoff, D. (2016). Throwing rocks at the Google bus: How growth became the enemy of prosperity. New York, NY: Penguin.

Saed. (2012). Capitalism Nature Socialism, 23(1), symposium on "Degrowth."

Salleh, A. (2009). Eco-sufficiency and global justice: Women write political ecology. London: Pluto Press.

Scheyvens, R. (2009). Pro-poor tourism: Is there value beyond the rhetoric? Tourism Recreation Research, 34(2), 191-196. doi:10.1080/02508281.2009.11081590

Sekulova, F., Kallis, G., Rodríguez-Labajos, B., \& Schneider, F. (2013). Journal of Cleaner Production, 38, special issue on "Degrowth: From theory to practice." doi:10.1016/j.jclepro.2012.06.022

Srisang, K. (1992). Third world tourism: The new colonialism. In Focus, 4, 2-3.

Slee, T. (2017). What's yours is mine: Against the sharing economy. London: Scribe.

Smil, V. (2013). Making the modern world: Materials and dematerialization. New York, NY: Wiley.

Smith, N. (1984). Uneven development: Nature, capital, and the production of space. Oxford: Basil Blackwell.

Spenceley, A. (2012). Responsible tourism: Critical issues for conservation and development. London: Routledge.

Srnicek, N. (2017). Platform capitalism. New York, NY: John Wiley \& Sons.

Srnicek, N., \& Williams, A. (2015). Inventing the future: Postcapitalism and a world without work. London: Verso Books.

Stroebel, M. (2015). Tourism and the green economy: Inspiring or averting change? Third World Quarterly, 36(12), 2225-2243. doi:10.1080/01436597.2015.1071658

Swyngedouw, E. (2010). Apocalypse forever? Post-political populism and the spectre of climate change. Theory, Culture \& Society, 27(2-3), 213-232. doi:10.1177/0263276409358728

United Nations (UN). (2016). Sustainable development goals. Retrieved from https://sustainabledevelopment.un.org/ sdgsproposal

United Nations Environment Programme (UNEP). (2011a). Towards a green economy: Pathways to sustainable development and poverty reduction. Nairobi: UNEP.

United Nations Environment Programme (UNEP). (2011b). Decoupling natural resource use and environmental impacts from economic growth. Nairobi: UNEP.

United Nations World Tourism Organization (UNWTO). (2009a). Roadmap to recovery. Retrieved from http://www. unwto.org/media/news/en/press_det.php?id=4181\&idioma $=\mathrm{E}$

United Nations World Tourism Organization (UNWTO). (2009b). Tourism status update. Retrieved from http://www. unwto.org/media/news/en/press_det.php?id=5061

United Nations World Tourism Organization (UNWTO). (2013). International tourism: An engine for the economic recovery. Press Release \# 13081. Retrieved from http://media.unwto.org/press-release/2013-12-12/internationaltourism-engine-economic-recovery 
United Nations World Tourism Organization (UNWTO). (2018). 'Overtourism'? Understanding and managing urban tourism growth beyond perceptions. Madrid: UNWTO.

United Nations World Tourism Organization (UNWTO). (2019). World tourism highlights 2018. Madrid: UNWTO.

Valdivielso, J., \& Moranta, J. (2019). The social construction of the tourism degrowth discourse in the Balearic Islands. Journal of Sustainable Tourism, 27(12), 1-17. doi:10.1080/09669582.2019.1660670

Wall, G. (1997). Sustainable tourism-Unsustainable development. In S. Wahab \& J. Pilgrim (Eds.). Tourism development and growth: The challenge of sustainability (pp. 29-43). London: Routledge.

Wanner, T. (2015). The new 'passive revolution' of the green economy and growth discourse: Maintaining the 'sustainable development' of neoliberal capitalism. New Political Economy, 20(1), 21-41. doi:10.1080/13563467. 2013.866081

Wolff, R. D. (2012). Democracy at work: A cure for capitalism. New York, NY: Haymarket Books.

World Commission on Environment and Development (WCED). (1987). Our common future. Oxford: Oxford University Press.

World Trade Market (WTM). (2017). $11^{\text {th }}$ Ministers summit. Retrieved from http://london.wtm.com/en/events/wtmministerial-programme/Ministers-Summit/

Young, G. (1973). Tourism: Blessing or blight? London: Penguin. 